\title{
Chronic unpredictable environmental stress impair biochemical and physiological homeostatsis: Role in diabetes mellitus
}

Alok Raghav ${ }^{1}$, Jamal Ahmad ${ }^{2 *}$, Imrana Naseem ${ }^{3}$

${ }^{1}$ Rajiv Gandhi Centre for Diabetes \& Endocrinology J.N Medical College, Aligarh Muslim University Aligarh, India.

${ }^{2}$ Rajiv Gandhi Centre for Diabetes \& Endocrinology J.N Medical College, Aligarh Muslim University Aligarh, India.

${ }^{3}$ Department of Biochemistry

Faculty of Life Sciences, Aligarh Muslim University Aligarh, India.

*Correspondence author

Prof. Jamal Ahmad

Rajiv Gandhi Centre for Diabetes \& Endocrinology

J.N Medical College

Aligarh Muslim University

Aligarh-202002, India

Email: jamalahmad11@rediffmail.com

Running Title: Chronic Unpredictable Environmental Stress 


\section{Abstract}

Chronic unpredictable environmental stress (CUES) may induce predisposition to diabetes mellitus. This study investigates the role of CUES on impaired homeostasis. Stressed group mice ( $n=20)$ were exposed to CUES for 16 weeks. Weekly body weight, feed consumption, feed efficiency ratio, fasting blood glucose were monitored. Plasma HbAlc, plasma cortisol, plasma epinephrine and plasma insulin, serum lipids, antioxidants and carbohydrate metabolizing enzymes activity were assessed along with DNA damage and histopathological examination of liver, kidney, pancreas, spleen and skeletal muscles. Fasting blood glucose levels \& HbA1c in the stressed were significantly higher compared to control $(\mathrm{p}<0.001)$. Serum lipids were found insignificantly higher in stressed mice compared to control. Body weights of the stressed mice and feed efficiency ratio were found significant $(p<0.001)$. Plasma corticosterone, plasma epinephrine, HOMA-IR was found to be significantly higher in the stressed group $(\mathrm{p}<0.001)$. Plasma insulin level was found to be significantly lower in the stressed group $(p<0.001)$. Significant changes were observed in antioxidants level, carbohydrate metabolizing enzymes activity, peripheral tissues and DNA integrity. CUES initiates pathogenesis of diabetes.

Keywords: Diabetes Mellitus, ROS, carbohydrate metabolism, Antioxidants, Chronic unpredictable environmental stress. 


\section{Introduction}

Stress is explained as the state of brain that interprets the stimulation quantity as excessive and threatening (Stacchiotti et al.,2006). Exposure to mechanical stressors results in an event of adaptive responses that help an organism to cope up with the dynamic environment (Carrasco and Van, 2003). Adequate acute stress may prove beneficial but if chronic, leads to complications and may be fatal (Esch et al., 2002). Chronic environmental unpredictable stress (CUES) in human is a most frequent type of stress that evokes drastic changes in blood circulation, hormone release, glucose metabolism along with behavioural alterations. Mechanistic hormonal pathway activated under chronic stress works via release of catecholamines and corticosteroids from the adrenal medulla and adrenal cortex respectively along with the release of adrenocorticotropin from the anterior pituitary(Carrasco and Van, 2003).

In humans, studies have demonstrated the onset of diabetes mellitus with chronic stress (Stein and Charles, 1971) and hyperglycemia (Surwit et al., 1992). The effect of CUES on glucose metabolism is mediated by counter-regulatory release of hormones resulting in hyperglycemia and impaired insulin action. Lipolysis equally contributes in progression of stress related complications via its lipotoxic effects on peripheral organs like muscles, liver, pancreas and kidney (Bays et al., 2008). Stress induced ROS is the predominant cause of DNA damage (Halliwell B, 2009). Recent studyshowedthe role of stress in development of insulin resistance in different tissues (Strommer et al., 1998). Physiological significances of carbohydrate metabolizing enzymes are unforgettable in CUES. Activity of hexokinase, glucokinase, fructose 1, 6 bis phosphatase and glucose -6-phosphatase can be exploited as marker for assessing the glucose metabolism inCUES. Stress besides causing impairement in carbohydrate metabolism also fosters the free radicals (Riley P.A, 1994). Although regulation of glycolytic flux is shared by all enzymes of the pathways but stress permits certain enzymes to perform its lead role. To maintain the homeostasis between production and removal of these ROS, there are antioxidants defense that includes superoxide dismutase, catalase, glutathione-S-transferase, glutathione peroxidase, gluthathione (GSH) reduce (Valko et al.,2007) . Certain cell types including neurons (Valencia et al., 2004) and beta cells (Hou et al., 2008) of the pancreas are very susceptible to ROS induced damage due to inherent low levels of free radical scavengers (Xu et al., 1999). With increase in CUES, the inherent free radical scavenging ability of the body further decreases (Hasan et al., 2013) and this results in severe damage leading to possible cause of diabetes. A recent literature showed 
the role of chronic stress on tissue histology and DNA damage due to ROS and stress proteins (Betsy et al., 2003).

The present study relate the effect of CUES on impairment of biochemical and histological homeostasis and their possible role in diabetic complications. Near genomic resemblance of mice with humans enable this study results to extrapolate with the humans. Therefore, this study aimed to implicate CUES of day to day human life to be tested in animal model.

\section{Material and methods}

\section{Ethical approval \& experimental animals}

Healthy 6-8 weeks old female Swiss albino mice (20 $\pm 5 \mathrm{~g})$ were obtained from central animal facility (401/RO/C/2001/CPCSEA) J.N Medical College, Aligarh Muslim University, India as per guideline laid down by CPCSEA (Ministry of Environment \& Forests, Govt. of India) and Institutional animal ethics committee, Aligarh Muslim University, India. The Institutional animal ethics committee, Faculty of Medicine, Aligarh Muslim University, India has approved the experimental procedure protocols. The all experiments were performed accordance with the the relavant guidelines and regulations laid down by the above committee.

\section{Housing and husbandry}

Animals were maintained under standard laboratory conditions in pathogen free environment under controlled factor of $12 \mathrm{~h}$ dark/light except on day 5 of protocol schedule. Housing room was maintained with ambient temperature of $22 \pm 2{ }^{\circ} \mathrm{C}$ with relative humidity of 50-60\%, 130-325 lux diffuse light except on day 5. Sterilized corncob bedding material was used to spread in the cages. During execution of protocol schedule, animals were fed on aqua guard filtered potable water and sterilized diet ad libitum to control and stressed mice (except day 7 of the protocol schedule to stress mice). Mice were sacrificed with sedation followed by cervical dislocation as per guideline of CPCSEA (Ministry of Environment \& Forests, Govt. of India) and Institutional animal ethics committee.

\section{Stressors}

The stressors used in the present study were as follows: (a) wire meshed cages attached to wooden board of individual animal size (b) tarsons animal cage 43x 27x 15 (lxbxh mm) with its bin 43x 27x 15 (lxbxh cm) (c) cylindrical tank $50 \mathrm{~cm}$ height x $20 \mathrm{~cm}$ (d) restrainer (e) compact fluorescent lamp.

\section{Study design}

Baseline control data for $\mathrm{HbAlc}$ and lipid profile were obtained from randomly selected 
mice considered to be initial control. Mice were randomly divided into two groups and stressed protocol of 16 weeks was carried out as represented in table I.

Group I (Control=20): Mice were allowed to ad libitum feed and water without performing any chronic unpredictable environmental stress procedure.

Group II(Stressed=20): Mice were subjected to chronic unpredictable environmental stress procedure for the period of 16 weeks.

\section{Experimental procedure}

CUES procedure was performed according to slightly modified previously described protocol (Hasan et al., 2011). Sequence of stressors were used for seven days continuously up to 16 weeks outlined in table I. Detailed CUES events are as follows: for restrain stress, all mice were kept in restrainer for period of 3 hours with no movement allowed. Wet bedding was performed by filling $500 \mathrm{ml}$ tap water in their home cages. Forced swim along with cold swim were carried out in cylindrical tank filled with tap water up to $25 \mathrm{cms}$ at $25^{\circ} \mathrm{C}$ and $4^{0} \mathrm{C}$ respectively. Crowding stress was performed by placing an iron sheet in their home cages to provide them minimum space to move. Illumination stress was achieved by placing CFL lamp overnight above cage. Mice were kept in separate sterilized autoclaved cages after each stress procedure. One baseline and one post-restraint sample were taken from stressed mice during the experimental protocol. Two days after baseline blood sampling, the mice of stressed group werestarted giving stress. Weekly fasting glucose (from second week) was recorded by tail prickmethod along with feed consumption \& body weight.

\section{Standard kits and reagent}

Serum lipid profile was done with standard biochemical kit (Avantor performance materials. Deventer, The Netherlands). HbA1c was estimated with standard kit (Recipe chemicals,Dessauerster 3, Gmbh, Germany). Fructose 1,6 bis phosphatase, glucose-6phosphatse, ATP,NADPH, sulphosalicyclic acid, gultathione reduced (GSH), cholorodinitro benzene (CDNB), folins reagent, bovine serum albumin (BSA), cysteine $\mathrm{HCl}$ and RPMI was purchased from Sigmachemical company (St. Louis, USA). Pyrogallol, $\mathrm{H}_{2} \mathrm{O}_{2}$, mannitol, succinic acid, sodium chloride, $\mathrm{KH}_{2} \mathrm{PO}_{4}, \mathrm{~K}_{2} \mathrm{HPO}_{4}$, EDTA, DTNB (Ellman's reagent), tris $\mathrm{HCL}, \mathrm{Na}_{2} \mathrm{CO}_{3}, \mathrm{NaOH}$, ferrous sulphate, ammonium molybdate, Mgcl2, Dglucose was purchased from SRL Chemicals (India).All other chemicals and reagents used were of highest analytical grade available.

\section{Collection of samples}

At termination of experiment, overnight fasted animals were sacrificed ethically; blood was 
collected in EDTAvials, centrifuged at $1500 \mathrm{~g}$ for $15 \mathrm{~min}$ and kept at $-20^{\circ} \mathrm{C}$ for estimation. Tissue samples werewashed with ice cold normal saline thrice. Homogenates of liver and pancreas were preparedfreshly for analysis in chilled phosphate buffer saline, $\mathrm{pH} 7.4$ with glass teflon homogenizer(REMI-RQ126/D) at 4000g for $20 \mathrm{mins}$ in ice filled glass beaker under chilling environment.Kidney homogenate was prepared in tris mannitol buffer to maintain the osmolarity. Protein content in tissue and serum sample was quantified according to previously described method (Rosebrough et al., 1951). Peripheral tissue for histopathology analysis was preserved in formal saline, while the tissue for comet assay was kept in RPMI media.

\section{Feed consumption and body weight}

Animal body weight and feed consumption were recorded once a week throughout the experiment duration of 16 weeks. The Feed efficiency ration was calculated as per equation given below:

Feed Efficiency Ratio = Body weight gain $(\mathrm{gms}) /$ Feed consumed $(\mathrm{gms})$ x 100

\section{Glycemic control estimation}

Estimation of glucose has been performed weekly in all mice of both groups by tail sniping method with glucometer (mylife Pura X, YPSOMED, Switzerland). Plasma samples of all animals were assessed for HbAlc measurement by standard kit (Recipe chemicals, Dessauerster 3, Gmbh, Germany) at the termination of experiment.

\section{Serum lipid profile}

Serum samples overnight fasting animals of both groups were processed for estimation of total cholesterol, HDL, triglycerides, LDL, and VLDL by colorimetric method (Avantor performance materials, Deventer, The Netherlands).

\section{Carbohydrate metabolizing enzymes activity}

Hexokinase (HK) activity was assayed in tissue samples of liver, pancreas and kidney to demonstrate glucose phosphorylation by previously described method (Brandstrup et al., 1957). Fructose 1,6 bis phophatase (F1, 6BPase) activity was estimated in liver , kidney and pancreas (Freedland and Harper, 1959). Glucose -6- phosphatase was assayed by previously described method (Baginski et al., 1974). Briefly incubation mixture was prepared in citrate buffer along with substrate and sample. Then reaction mixture for 1 hour was incubated at 37 0C. Termination of the reaction in the incubation mixture was performed with the addition of $10 \%$ TCA solution followed by centrifugation at $5000 \mathrm{x}$ g for $10 \mathrm{mins}$. The phosphorous content was estimated in the suspension according to previously described method (Nordlie et al., 1965). 


\section{Estimation of reactive oxygen species (ROS) scavengers}

\section{Superoxide Dismutase (SOD)}

SOD activity in tissue and serum was determined by measuring the inhibition of autooxidation of pyrogallol in $0.05 \mathrm{M}$ tris succinate buffer (pH 8.2) at wavelength of $412 \mathrm{~nm}$. SOD activity was estimated with previously described method (Marklund et al., 1974). The results obtained were expressed as specific activity in units/mg protein.

\section{Catalase (CAT)}

Serum and tissue catalase activity was measured with $0.05 \mathrm{M}$ phosphate buffer ( $\mathrm{pH}$ 7.0) as previously explained method 23 . The decrease in the absorbance at $240 \mathrm{~nm}$ due to oxidation of $30 \mathrm{mM}$ hydrogen peroxide $\left(\mathrm{H}_{2} \mathrm{O}_{2}\right)$ was recorded for the estimation of activity. The results were expressed as specific activity in units/mg protein sample.

\section{Glutathione reduced (GSH)}

Serum and tissue homogenate reduced glutathione (GSH) activity was estimated by previously described method ${ }^{24}$. Briefly equal amount of sulphosalicyclic acid was added to sample and then incubated for $1 \mathrm{hr}$ at $4^{0} \mathrm{C}$. Incubated sample was then centrifuged at $12000 \mathrm{xg}$ for $15 \mathrm{~min}$ at 40C. DTNB (Elman's reagent) was then added to the supernatant in potassium phosphate buffer $(0.1 \mathrm{M}, \mathrm{pH}=7.4)$ and yellow colour developed was read at $412 \mathrm{~nm}$. The results obtained were expressed as nmol/mg protein.

\section{Gluthathione-s-transferase (GST)}

GST activity in serum and tissue homogenate was assessed in $0.2 \mathrm{M}$ phosphate buffer ( $\mathrm{pH}$ 6.5) as previously described protocol ${ }^{14}$. Freshly prepared GSH was dissolved in potassium phosphate buffer followed by addition of CDNB (1mM) (Chloro-dinitrobenzene) prepared in acetone. Samples were read at $340 \mathrm{~nm}$ and activity was calculated as units/mg of protein.

\section{Glutathione peroxidase (GPx)}

Glutathione peroxidase (GPx) activity in tissue homogenate and serum was determined ${ }^{25}$. Tissue homogenate was centrifuged at $4000 \mathrm{rpm}$ for $5 \mathrm{~min}$ and washed gently with $0.1 \mathrm{M}$ potassium phosphate buffer ( $\mathrm{pH}$ 7.4) having EDTA (1mM). GPx activity was calculated using an extinction coefficient of 6.22 millimolar extinction coefficient of $\beta$ NADPH at $340 \mathrm{~nm}$.

\section{Tissue Histopathology}

The mice were sacrificed by cervical dislocation and liver, kidney, pancreas, and glycolytic skeletal muscles were taken for histopathology. Tissues were fixed in 10\% formalin in PBS, embedded in paraffin, and cut into 3-5- $\mu \mathrm{m}$ thick sections with 
rotary microtome and stained with hematoxylin and eosin stain. Stained slides were observed under trinocular light microscope (Olympus BX40, Japan).

\section{Comet Assay}

The comet assay of liver, pancreas and kidney was done as previously described protocol ${ }^{26}$ with few modifications. Precoated and frosted slides with 1\%normal melting agarose (as base layer) were prepared a day before sacrificing the mice. About10,000 cells isolated from each organ cell suspension were mixed with $100 \mathrm{ml} \mathrm{1 \%}$ of lowmelting point agarose to form the working cell suspension. This suspension was pipetted over the base layer at $37^{\circ} \mathrm{C}$ followed by covering with cover slips immediately. After solidification, at hird layer of $0.5 \%$ LMPA $(100 \mathrm{ml})$ was placed over followed by covering with cover slips and kept on ice packs again. Slides were dipped for 3 hours in cold lysing solution $(2.5 \mathrm{M}$ $\mathrm{NaCl}+100 \mathrm{mM}$ EDTA $+10 \mathrm{mM}$ tris-base $+1 \%$ triton $\mathrm{X}-100, \mathrm{pH}=10$ ). Later, slides were allowed to unwind for $30 \mathrm{~min}$ in alkaline electrophoretic running buffer $(300 \mathrm{mM} \mathrm{NaOH}+$ $1 \mathrm{mM}$ EDTA, $\mathrm{pH}=13)$. Then, electrophoresis was performed for 35 minutes at $40 \mathrm{C}$ with constant current strength of $300 \mathrm{~mA}$. Slides were placed in neutralizing buffer $(0.4 \mathrm{M}$ trisbase) of $\mathrm{pH} 7.5$ followed by washingwith cold saline thrice. The process of neutralizationfollowed by washing was repeated thrice. Staining of slides was performed with $80 \mathrm{ml}$ ethidium bromide $(20 \mathrm{mg} / \mathrm{ml})$. EtBr stained slides were scored with fluorescent microscope (Olympus,Japan) coupled with an image analysis system (Komet 5.5, Kinetic imaging, Liverpool, U.K.)Comet tail-length (migration of DNA from its nucleus in $\mathrm{mm}$ ) was measured to assess the levelof DNA damage.

\section{Estimation of stress hormones, Insulin and HOMA-IR}

Blood was extracted from mice during early morning timings for estimation of stress hormones. Plasma epinephrine quantity were estimated using mouse epinephrine ELISA kit (procured from Abnova, KA1882, Taiwan). The protocol manual procedure supplied by the kit manufacturer was followed. Plasma corticosterone were determined using mouse corticosterone ELISA kit (procured from Abnova, KA0468, Taiwan). Furthermore, the protocol supplied in the manual was followed. The plasma insulin was measured by mouse enzyme-linked immunosorbent assay (ELISA) kit (Mercodia, Sweden) (Intra- and interassay coefficienct of variations were $3.40 \%$ and $2.20 \%$ respectively). The Homeostatic model assessment-Insulin resistance was calculated for each group with given equation below:

HOMA-IR = fasting glucose level $(\mathrm{mmol} / \mathrm{L}) \times$ fasting insulin level $(\mu \mathrm{U} / \mathrm{mL}) / 22.5$ 


\section{Statistical Analysis}

All statistical analysis of results was performed with Statistical Program of Social Sciences(SPSS) for windows 7 version. Results of the analysis were expressed as mean+SD and the significant difference between control and stressed group was determined by using unpaired student's t-test. Repeated measure analysis of variance (RMANOVA) was used to evaluate the statistical significance among bodyweight, fasting plasma glucose and feed consumption of stressed and control mice. A $p$ value of $<0.05$ was considered to be significant.

\section{Results}

\section{Effect of CUES on body weight and latency to consume feed}

One way repeated ANOVA (RMANOVA) statistical analysis of animal body weight showedthat chronic exposure to environmental unpredictable stressed group resulted in decrease in body weight compared to control group (Fig 1a) Table II. Significant changes were not found in the feed consumption attributed of all stressed mice compared to control (Fig 1b) Table II. The latency to consume feed in stressed group was found less as compared to control. The feed efficiency of control group was found to be higher than treatment group $(\mathrm{p}<0.001)$ Table II.

\section{Glycemic control assessment}

Fasting blood glucose level in stressed mice was found significantly higher that control group. Moreover, increase in fasting blood glucose was observed from second week of initiation of experiment in stressed group (Fig 1c) Table II. HbA1c results showed significant increase in stressed group $(7.1 \pm 0.13 \%)$ compared to control mice $(6.15 \pm 0.31 \%)$ at 16 th week with a $\mathrm{p}$ value of $0.0002(\mathrm{~F}=3.369, \mathrm{df}=8)$.

\section{Serum lipid profile}

No significant change in lipid and lipoproteins were observed in stressed group as compared to control mice. Serum cholesterol, HDL, LDL, VLDL and triglycerides in stressed mice after 16 week stress protocol were $161+63.98 \mathrm{mg} / \mathrm{dL}(\mathrm{p}=0.6260)(\mathrm{F}=5.68, \mathrm{df}=8), 40.72+16.30 \mathrm{mg} / \mathrm{dL}$ $(\mathrm{p}=0.5516)(\mathrm{F}=13.67, \mathrm{df}=8), 86.29+48.52 \mathrm{mg} / \mathrm{dL}(\mathrm{p}=0.8332)(\mathrm{F}=3.689, \mathrm{df}=8), 34+7.12 \mathrm{mg} / \mathrm{dL}$ $(p=0.2088)$ and $170+35.61 \mathrm{mg} / \mathrm{dL}(\mathrm{p}=0.2088)$ respectively, insignificantly higher than serum cholesterol, HDL, LDL, VLDL and triglycerides $145+29.82 \quad \mathrm{mg} / \mathrm{dL}, 35.74+7.43$ $\mathrm{mg} / \mathrm{dL}, 81.10+22.32 \mathrm{mg} / \mathrm{dL}, 28.16+6.36 \mathrm{mg} / \mathrm{dL}$ and $140.8+31.82 \mathrm{mg} / \mathrm{dL}$ respectively in the control group. 


\section{Carbohydrate enzymes activity}

The significant changes were found in activity of hexokinase (HK), and glucose-6phosphatase in stressed mice compared to controls. Activity of F1, 6 BPase decreased in stressed mice compared to control but is not significant statistically. The results obtained showed that CUES alters the carbohydrate metabolism in liver, kidney and pancreas homogenate as shown in table III.

\section{Antioxidants activity}

Serum SOD, catalase, GSH, GST\& Gpx activity in stressed mice were significantly lower than ofcontrol mice as shown in table III. Furthermore, antioxidants activities in liver, kidney andpancreas demonstrated significant decrease activity in stressed mice (table III). Results of thisstudy clearly reflect the relation of CUES in the alteration of ROS scavenger expression.

\section{Histopathology}

Histopathological studies of the liver, kidney, pancreas and glycolytic skeletal muscles for elucidation ofchronic stress severity have been reported as one of the pivotal approach. Chronic stress severely affects the histology of these peripheral tissues as shown in Fig 2.

\section{Comet Assay}

Chronic stress exposure in stressed mice caused prominent DNA damage in the kidney, liver and pancreas as evidenced by tail length elongation with respect to control mice. Significant change in tail length was observed in stressed mice compared to control as shown in Fig 3 (table IV).

\section{Estimation of plasma stress hormone, insulin and HOMA-IR.}

The mean values of plasma epinephrine was found significantly higher in mice of stressed group $(21.66 \pm 1.99 \mathrm{pg} / \mathrm{mL})$ compared to control mice $(13.15 \pm 2.11 \mathrm{pg} / \mathrm{mL}) P>0.05$. Moreover plasma cortisol levels in stressed mice are found to be $46.62 \pm 1.99 \mathrm{ng} / \mathrm{mL}$, which is significantly higher than the control mice $16.11 \pm 2.19 \mathrm{ng} / \mathrm{mL}$ respectively $(P>0.05)$. Plasma fasting insulin and HOMA-IR was demonstrated in table V.

\section{Discussion}

The present study demonstrated the adverse effect of 16 weeks CUES on carbohydrate metabolism, lipids profile, glycemic control and antioxidants activity. Significant decrease in body weight was observed in stressed mice as compared to control group. Feed intake was also found lower in stressed group. The significant decrease in feed efficiency ratio (FER) was found in stressed group compared to control mice. The increased FER in control group is the suggestive of body weight gain occurred due to normal glucose 
metabolism. Significant increase in fasting blood glucose and HbAlc at $16^{\text {th }}$ week was found in stressed mice compared to control group. An insignificant change in lipid profile was observed in the stressed group as compared to control group. The increase in serum lipids and lipid proteins were insignificant probable due to less number of animals in each group that could not reach at statistical significance. The present study also deciphers the alterations in antioxidants activities as a resultant of CUES. In stressed group, decrease activities of CAT, SOD, GST, Gpx and GSH were found compared to control mice. Hexokinase activity in stressed mice was significantly higher than control mice. However an insignificant increase in activities of F 1, 6BPase and glucose-6-phosphatase were found in stressed mice compared to control animals. It is well known, that chronic psychological stress decreases biological resilience,impairs homoeostasis of living system and induces changes in various physiological functions leading to pathological complications ${ }^{27}$. Moreover, several published literature reflects the adverse effect of chronic stress on hereditary unit integrity ${ }^{28}$. These changes would be due to significant increase in the ROS and deleterious effect on beta cells resulting in alterations in carbohydrate metabolism. A previous study reported that stress induced release of corticotrophin releasing hormone (anorexigenic neuropeptide) therebyleads to the decrease in the latency of feed consumption and body weight, producing a "negative energy balance" and increase in corticosterone release ${ }^{29}$.

Impairment of glycemic control could be the combo of two mechanistic pathways, hyperglycaemic environment of release of glucocorticoids and catecholamines upon activation of sympatho-adreno-medullary and pituitary-adreno-cortical scheme respectively ${ }^{2-3}$. Chronic stress results in elevated plasma catecholamine along with corticosterone that constitutes fight or flight response thereby stimulating glycogenolysis resulting in increase metabolic rate and glucose concentration in body. This hyperglycaemic environment enables haemoglobin susceptible for glycation ${ }^{30}$.

Cholesterol synthesis occurs in liver is governed by series of transcriptional factors primarily sterol regulatory element binding protein $2\left(\right.$ SREBP2) ${ }^{31}$ which lead to increased expression of cholesterol. Chronic stress mobilizes lipids in circulation to cope with flight and fight response ${ }^{32}$. The lipids can be oxidized to restore energy and used for gluconeogenesis ${ }^{31}$. Rodent trials have also been found to have higher cholesterol level among stressed group compared to control ${ }^{33}$. The dynamic mobilization of lipids due to stress increases catecholamines mediated expression of adipose triglycerides lipase and hormone sensitive lipase ${ }^{34}$. Catecholamine also plays subsidiary role in the phosphorylation and activation of hormone sensitive lipase, as a results perilipin protein gets phophorylated and a 
conformational change occurs that allows lipases to retain in contact with lipids ${ }^{35}$. In addition to this stress induces the activation of glucagon, cortisol and catecholamines that activates phosphatidate phosphohydrolase which in turn results in increase of hepatic triglycerides synthesis. Similarly stress induced release of glucocorticoids and free fatty acid stimulate the activation of HMG-CoA reductase of liver thereby synthesizing cholesterol ${ }^{36}$. Increase level of VLDL during stress was also found in this study, this may be due to high supply of free fatty acids via lipolytic mechanism effect ${ }^{34}$.

The antioxidant enzymes demonstrate the first line of defence against reactive oxygen species and their decrease activities may contribute to the oxidative stress. A published literature also reported exposure to 21 days stress decreases GSH activity ${ }^{16}$. GST activity was also found to decrease during chronic stress exposure due to altered glutathione metabolism and impaired antioxidant defense pathways. The overall impairment in the antioxidant defense system and biochemical parameters may be due to high depletion of both deep energy (stored) and superficial energy (ready to use) during exhaustion phase of chronic stress. A recent study on chronic stress also demonstrates the adverse effect on carbohydrate metabolism in male albino rats ${ }^{37}$. The decrease activity of catalase during stress could be due to combinatorial effect of depletion of NADPH, lipid peroxidation and excessive production of free radicals ${ }^{38}$. The decrease in GPx, GSH and GST activity might be because of depletion or inactivation of the enzyme by stress induced ROS ${ }^{38}$. The reduction of catalase and SOD activity may also be due to either loss of substrate $\mathrm{H}_{2} \mathrm{O}_{2}$ or their less transcription due to overproduction of ROS.

CUES induced downfall in the activity of glucose-6-phopshatse dehydrogenase results in diminished operation of pentose phosphate pathway and thereby enhances the production of reducing molecules such as NADH and NADPH ${ }^{39}$. In the current study administration of the CUES protocol decrease the glucose-6-phosphatase activity thereby causing activation of pentose phosphate pathway and increase in NADPH due to inactivation of sorbitol pathway ${ }^{40}$. It could be noticed that in stressed group, the glycogenolysis is enhancing the production of endogenous glucose and along with its peripheral utilization. Constrastingly, the HK activity was significantly reduced in stressed mice suggesting decrease phosphorylation of hepatic glucose after stress stressed. Gluconeogenic enzymes (G-6-Pase and F1,6 BPase) showed parallel decrease in its activities. As for experimental stress, our results showed that besides hyperglycemia there is also decrease in glycogenolytic and glycolytic enzymes (G6-Pase, and HK) activity. The present study also shows distinct pattern of enzyme activity expression. The decrease in hexokinase activity in stressed group is a marked evidence 
of consistent hyperglycemia as insufficient amount of glucose is reaching to liver even in high glycemic control ${ }^{41}$. However, the stress group also showed decrease activity in G6Pase thereby giving an insight on glucose homeostasis ${ }^{39}$.

As shown in results that significant decrease of gluconeogenesis enzymes was found hampered by CUES. The decrease in gluconeogenic enzymes may also hampers the enzymes of TCA cycle. CUES allow the release of epinephrine and norepinephrine into the blood stream by adrenal glands that in turn stimulate the pancreatic $\alpha$ cells to secrete glucagon. This released hormone binds to $\beta$ adrenergic receptors and stimulates adenylate cyclise and produces cAMP along with inositol-1,4,5-triphosphate(IP3), diacylglycerol (DAG) and $\mathrm{Ca}+2$ ,also with the activation of $\alpha$ adrenergic receptors. The liver's response to chronic stress incorporates the participation of two secondary messenger systems. cAMP mediate the stimulation of glycogenolysis and inhibition of glycogen synthesis and thereby inactivate the glycogen synthase. This stimulation event hampers the glucose metabolismand allows hyperglycemia to persist.

The changes in peripheral tissues that include liver, kidney, pancreas, spleen and skeletal muscles are also remarkable finding of present study. Liver of control group of mice shows normal hepatic cells, hepatic veins and prominent central vein. While after administration of stress, degenerative changes were observed in hepatic cells, several vacuolated spaces were observed along with clustered nuclei suggestive of fatty liver (Fig 2). Control group of mice shows normal glomerulus in kidney along with both proximal and distal convoluted tubules and bowmen's capsule. Stressed mice kidney shows clustered nuclei in glomerulus with frequent degeneration of cytoplasm along with dilated and flattened bowmen's capsules. The above changes in the liver and kidney histology may be due to release of the stress proteins HSP25, HSP72, GRP-75 after chronic exposure to stress (Fig 2) 1. Pancreas of the control group shows normal structure of islets cells, whereas in stress group, pancreatic islets cells show lymphocytic infiltration as shown in Fig 2. Stress induced free radicals readily damages the beta cells of the islets, thereby causing insulinitis as reported previously in the literature ${ }^{42}$. Skeletal muscles in stressed group show moderate congestion of blood capillaries along with mild hyperplasia compared to control mice probably due to chronic stress that alters the normal secretion of Insulin like growth factor (IGF). IGF mediates the insulin metabolism and stimulates protein synthesis. Two types of IGF are found in skeletal muscles IGF-I and IGF-II that are responsible for proliferation and differentiation of satellite cells. In response to chronic stress, the IGF-I levels enhance and cause the hypertrophy and hyperplasia of skeletal muscles as reported 
earlier. The observed changes in spleenic red pulp and white pulp in the stress group showed vacuolated spaces and megakaryocytes.

A significant quantity of DNA damage in terms of increased comet tail length was observed in the liver, pancreas and kidney of stressed mice (3). A plausible and easy approach to understand this damage lies with the explanation of ROS production in high concentration due to chronic exposure of the stress in stressed mice. Previously reported literature demonstrates stressinduced double strand breaks in the DNA (Grek, et al. 2010). Deoxyribose backbone in theDNA is the accessible target for ROS thus initiating oxidative DNA lesions ${ }^{15}$. ROS primarily indirectly attack other cellular components generatingsecondary reactive intermediates that forms DNA adduct irreversibly. Thus chronic stress lead toimpairment in the homeostasis and ROS mediated damage to DNA as measured by comet taillengths. The mechanism of environmental stress on ROS mediated DNA damage has been demonstrated in figure 4.

The aim to measure plasma cortisol and epinephrine in present study is to evaluate the effect of CUES on body homeostasis. These hormones are secreted in emergency situation and in stress reponse ${ }^{43}$. The presence of variable and chronic stress during the perod of experiment when exceed the threshold may activate HPA (hypothalamus -pituitary axis) mediated by central afferent cycle that contribute in release of stress hormones ${ }^{44}$. Adrenal cortex region secretes two forms of glucocorticoids that includes (a) active and (b) inactive, both act as stress indicator ${ }^{45}$. Hence the estimation of cortisol and epinephrine in stressed mice indicate the suffering from chronic stress that impair the homeostasis of system.

\section{Conclusion}

The present study concludes that CUES in female Swiss albino mice for period of 16 weeks leads to decrease in antioxidants activities and alterations in carbohydrate metabolizing enzyme expression. CUES induced hyperglycemia impairs the metabolism and free radicals scavenging significantly. Histopathology examination and comet assay reveals the fact that exposure to chronic stress is harmful at tissue level also.

\section{Funding}

We are thankful to Council of Scientific \& Industrial Research, New Delhi, India for the award for financial support with award number EMR-II/37(1577)/13.

\section{Acknowledgement}

The contribution of Mr. Asim Rizvi is being acknowledged for his conceptual idea at the time 
of submission of the project to CSIR.

\section{Author's contribution}

Conceptualization: AR, JA, IN.

Data curation: JA, IN.

Formal analysis: AR, JA, IN, BKM, ZAK

Investigation: AR, BKM, ZAK

Methodology: AR, BKM, ZAK

Project administration: JA, IN.

Resources: JA, IN.

Software: AR.

Supervision: JA, IN.

Validation: JA, IN.

Visualization: AR, JA.

Writing - original draft: AR.

Writing - review \& editing: JA, IN.

\section{Conflict of Interest}

The authors have declared that there is no conflict of interest.

\section{Abbreviations Used}

CUES $=$ Chronic unpredictable environmental stress

$\mathrm{n}=$ Number of animals in each group

$\mathrm{HDL}=$ High density lipoprotein

$\mathrm{LDL}=$ Low density lipoprotein

$\mathrm{VLDL}=$ very low density lipoprotein

CPCSEA $=$ Committee for the Purpose of Control and Supervision of Experiments on Animals

lxbxh= length $\mathrm{x}$ breadth $\mathrm{x}$ height

$\mathrm{mm}=$ millimetre

$\mathrm{cm}=$ centimetre

${ }^{0} \mathrm{C}=$ degree centigrade

$\mathrm{CFL}=$ Compact fluorescent lamp

Fig= Figure 


\section{References}

1. Stacchiotti A., Rodella L.F., F. Ricci, Rezzani R., Lavazza A. and Bianchi R. Stress proteins expression in rat kidney and liver chronically exposed to aluminum sulphate. Histol Histopathol 21: 131-40 (2006).

2. Carrasco GA and Van de Kar LD. Neuroendocrine pharmacology of stress. Eur $J$ Pharmacol. 463:235-72 (2003).

3. Esch T, Stefano GB, Fricchione GL and Benson H. Stress in cardiovascular diseases. Med Sci Monit 8:RA93-RA101 (2002).

4. Stein SP and Charles E. Emotional factors in juvenile diabetes mellitus: a study in the early life experiences of adolescent diabetes. Am J Psychiatry 28:700-4 (1971).

5. Surwit RS, Schneider MS and Feinglos MN. Stress and diabetes mellitus. Diab Care 15:1413-22 (1992).

6. Bays HE, González-Campoy, JM, Bray GA. et al. Pathogenic potential of adipose tissue and metabolic consequences of adipocyte hypertrophy and increased visceral adiposity. Ex. Rev. Cardiovasc. Ther. 6:343-68 (2008).

7. Halliwell B. The wanderings of a free radical. Free Radic Biol Med 46:531-42 (2009).

8. Strommer L, Permert J, Arnelo U, Koehler C, Isaksson B, Larsson J, et al. Skeletal muscle insulin resistance after trauma: insulin signaling and glucose transport. Am J Physiol 275:E351-8 (1998).

9. Riley P.A. Free radicals in biology: Oxidative stress and effects of ionizing radiations. Inf. healthcare 65(1), 27-33 (1994).

10. Valko M, Leibfritz D, Moncol J, Cronin MTD, Mazur M and Telser J. Free radicals and antioxidant in normal physiological function and human disease. Int $J$ Biochem Cell Biol 39:44-84 (2007).

11. Valencia A and Moran J. Reactive oxygen species induce different cell death mechanisms 
in cultured neurons. Free Rad. Biol and Med 36(9):1112-25 (2004).

12. Hou Ni, Torii Seiji, Saito Naoya, Hosaka Masahiro and Takeuchi Toshiyuki. Reactive Oxygen Species-Mediated Pancreatic $\beta$-Cell Death Is Regulated by Interactions between Stress-Activated Protein Kinases, p38 and c-Jun N-Terminal Kinase, and Mitogen-Activated Protein Kinase Phosphatases. Endocrinology 149(4):1654-65 (2008).

13. Xu Bo, Moritz Jon $\mathrm{T}$ and Paul Epstein N. Overexpression of catalase provides partial protection to transgenic mouse beta cells. Free Rad. Biol. and Med 27: 230-37 (1999).

14. Hasan Shirin, Fatima Naureen, Bilal Nayeem, Suhail Nida, Fatima Sabiha, Morgan Enas N., Aldebasy Yousef, Alzohairy Mohammad A. and Banu Naheed. Effect of chronic unpredictable stress on short term dietary restriction and its modulation by multivitamin-mineral supplementation. Appetite 65 68-74 (2013).

15. Betsy M. Sutherland, Alexandros G. Georgakilas, Paula V, Bennett, Jacques Laval and John C. Sutherland. Quantifying clustered DNA damage induction and repair by gel electrophoresis, electronic imaging and number average length analysis. Mut. Res. 531: 93107 (2003).

16. Hasan Shirin, Bilal Nayeem, Naqvi Shoa, Ashraf Ghulam Md, Suhail Nida, Sharma Sadhna and Banu Naheed. Mulltivitamin-mineral and vitamins $(E+C)$ supplementation modulate chronic unpredicatable stress-induced oxidative damage in brain and heart of mice. Biol Trace Elem Res 142 (3), 589-97 (2011).

17. Rosebrough NJ, Farr AL and Randall RJ. Protein measurement with the Folin phenol reagent. J Biol Chem 193:265-75 (1951).

18. Brandstrup N, Kirk J. E, and Brunic C. Determination of glucokinase in tissues. $J$. Gerontol. 12: 166-71 (1957).

19. Freedland R. A. and Harper A. E. The study of metabolic pathway by means of adaptation. J. Boil. Chem 234:1350-54 (1959). 
20. Baginski, E.S, Foa P.P and Zak B. Glucose 6-phosphatase. In methods of enzymatic analysis. Ed. I Gulman and H.U Bergmeyer. NY Acad Press 1794-97 (1974).

21. Nordlie RC, Arion WJ and Glende EA Jr. Liver microsomal glucose 6-phosphatase, inorganic pyrophosphatase, and pyrophosphate-glucose phosphotransferase. IV. Effects of adrenalectomy and cortisone administration on activities assayed in the absence and presence of deoxycholate. J Biol Chem. 240 (9):3479-84 (1965).

22. Marklund, S., \& Marklund, G. The involvement of the superoxide anion radical in the auto oxidation of Pyrogallol and a convenient assay for superoxide dismutase. Eur J. of Bio. 47, 469-74 (1974).

23. Claiborne, A. Catalase activity. In R. A. Green Wald (Ed.), CRC handbook of methods for oxygen radical research. Boca Raton, FL: CRC Press 283-84 (1985).

24. Jallow DJ, Mitchell JR, Zampaglione $\mathrm{N}$ and Gillote JR. Bromobenzene induce liver necrosis: Protective role of glutathione and evidence for 3, 4-bromobenzene oxide as the hepatotoxic metabolite. Pharmacology. 11-:151-69 (1974).

25. Lawrence R.A and Burk R.F. Glutathione peroxidase activity in selenium- deficient rat liver. Biochem. Biophys. Res. Commun 71, 952-58 (1976) .

26. Hassan Iftekhar, Chibber Sandesh, Khan Aijaz A. and Naseem Imrana. Riboflavin Ameliorates Cisplatin Induced Toxicities under Photoillumination. PLoS ONE 7(5): e36273 (2012).

27. Lin Yan-Hua, Liu Ai-Hua, Xu Ying, Tie Lu, Yu He-Ming and Li Xue-Jun. Effect of chronic unpredictable mild stress on brain-pancreas relative protein in rat brain and pancreas. Behav Brain Res 165(1), 63-71 (2005).

28. Hara MR, Kovacs JJ, Whalen EJ, Rajagopal S, Strachan RT, Grant W, Towers AJ, Williams B, Lam CM, Xiao K, Shenoy SK, Gregory SG, Ahn S, Duckett DR and Lefkowitz RJ. A stress response pathway regulates DNA damage through $\beta 2$-adrenoreceptors and $\beta$ - 
arrestin-1. Nature 477(7364):349-53 (2011).

29. Leibowitz SF and Wortley KE. Hypothalamic control of energy balance: different peptides, different functions. Peptide 25:473-504 (2004).

30. Raghav Alok and Ahmad Jamal. Glycated serum albumin: A potential disease marker and an intermediate index of diabetes control. Diab. Metab Syndr: Clin. Res. \& Rev. 8(4): 245-51 (2014).

31. Georgiadi Anastasia and Kersten Sander. Mechanisms of Gene Regulation by Fatty Acids. Adv. Nutr 3: 127-34 (2012).

32. Yehuda S, Rabinovitz S, Carasso RL, et al. Fatty acid mixture counters stress changes in cortisol, cholesterol, and impair learning. Int J Neurosci 101(1-4):73-87 (2000).

33. Degordoa JCR, Santafe J, Domenech JS, et al. Modification of rat plasma-lipoproteins induced by acute immobilization stress. Psych. Med. 56(6):486-92 (1994).

34. Rosenfeld M. Lipid Digestion and Absorption, Fatty Acid Synthesis and Oxidation, Triglyceride Synthesis, Adipose Tissue Lipoprotein Metabolism, Cholesterol, Lipid Metabolism in Pregnancy and Lactation. Presented at Nutrition and Metabolism II, University of Washington, Seattle WA (2012).

35. Robin E. Duncan, Maryam Ahmadian, Kathy Jaworski, Eszter Sarkadi-Nagy, and Hei Sook Sul. Regulation of Lipolysis in Adipocytes. Annu Rev Nutr 27: 79-101 (2007).

36. Michael R. Flock, Michael H. Green, and Penny M. Kris-Etherton. Effects of Adiposity on Plasma Lipid Response to Reductions in Dietary Saturated Fatty Acids and Cholesterol. Adv Nutrvol 2: 261-74 (2011).

37. Nirupama R., Devaki M., and Yajurvedi H.N. Chronic stress and carbohydrate metabolism: Persistent changes and slow return to normalcy in male albino rats. Stress 15(3):262-71 (2012).

38. Zafir, A and Banu N. Modulation of in vivo oxidative status by exogenous corticosterone 
and restraint stress in rats. Stress 12 (2), 167-77 (2009).

39. Pari Leelavinothan and Suman Selvaraju. Efficacy of Naringin on Hepatic Enzymes of Carbohydrate Metabolism In Streptozotocin - Nicotinamide Induced Type2 Diabetic Rats. Int J of Pharma \& Biol Arch 1(2): 280 - 86 (2010).

40. Giacco Ferdinando and Brownlee Michael. Oxidative stress and diabetic complications. Circ Res 107(9): 1058-70 (2010).

41. Rizkalla Salwa W. Health implications of fructose consumption: A review of recent data. Nutr. \& Metab 7:82 (2010).

42. Anderson Pan. J. R. Muir's Textbook of Pathology. ELBS 12th ed. pp. 20-63 (1985).

43. Stinnett G. S. and SeasholtzA. F. "Stress and emotionality," in Encyclopedia of Behavioral Neuroscience, G. F. Koob, M. Le Moal, and R. F. Thompson, Eds., pp. 316-321, Elsevier, 2010.

44. DeBold, C.R., Sheldon, W.R., DeCherney, G.S., Jackson, R.V., Alexander, A.N., Vale, W., Rivier, J., Orth, D.N. Arginine vasopressin potentiates adrenocorticotropin release induced by ovine corticotropin-releasing factor. J. Clin. Invest. 73, 533-538 (1984).

45. PeckettA. J., WrightD. C., and RiddellM. C. The effects of glucocorticoids on adipose tissue on lipid metabolism. Metab. Clin. and Exp. 60: 1500-1510, (2011).

\section{Figure legends}



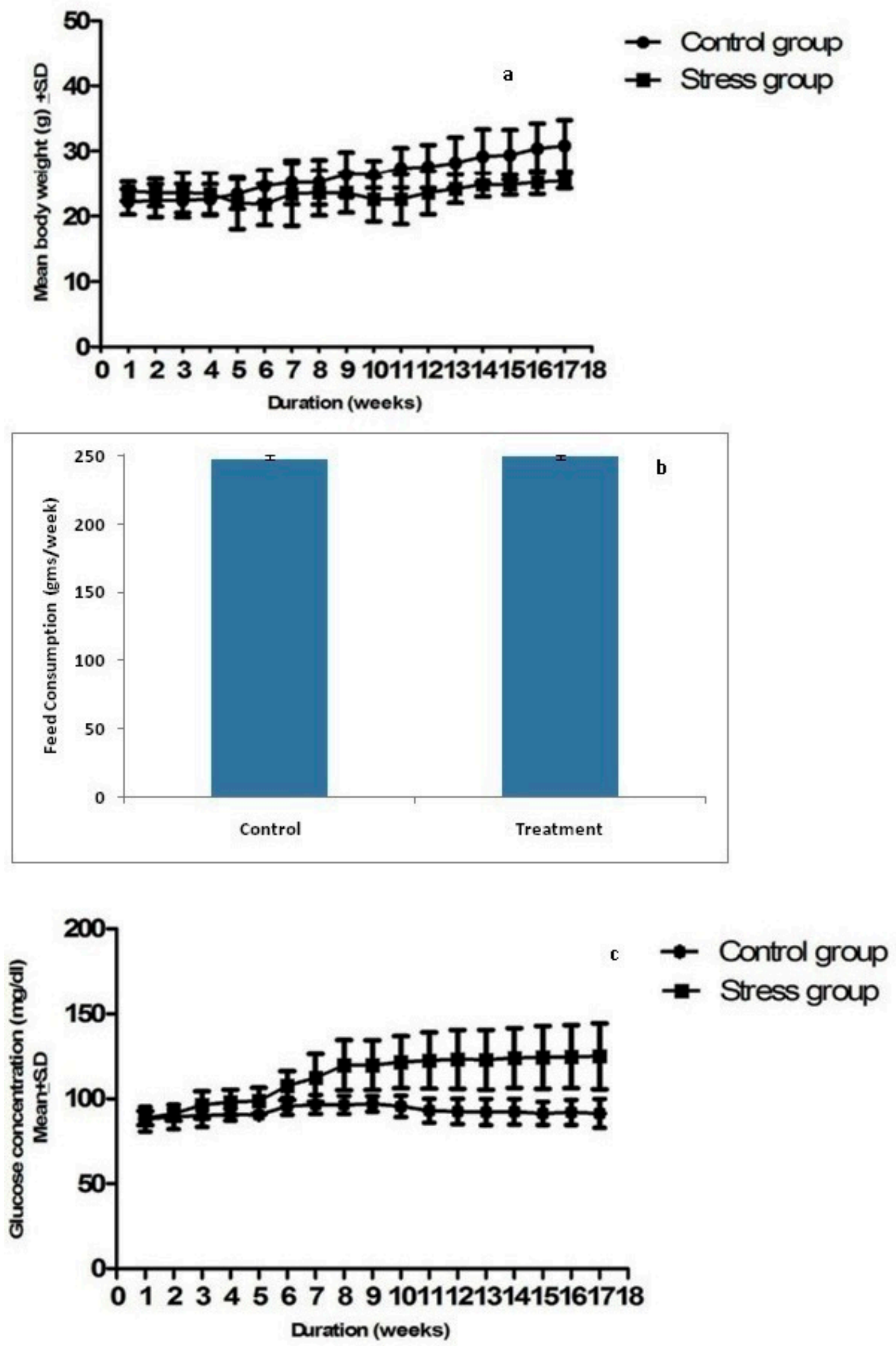
Figure 1a: Evaluation of chronic unpredictable environmental stress on mean body weight in gms. Stressed mice were showing significant decrease in mean body weight compared to control $(\mathrm{p}<0.05)$. Data are presented as mean_-S.D. (1b) Effect of chronic unpredictable environmental stress on feed consumption. Stressed mice were showing no significant changes in feed consumption compared to control mice. Feed consumption recorded in grams consumed per week. (1c) Evaluation of chronic unpredictable environmental stress on weekly plasma fasting glucose $(\mathrm{mg} / \mathrm{dl})$. Stressed mice were showing significant increase in fasting plasma blood glucose compared to control. Data are presented as mean $\_$SD. A p value $<0.05$ were considered as significant ( $n=20$ in each group). 
(A) Control Liver
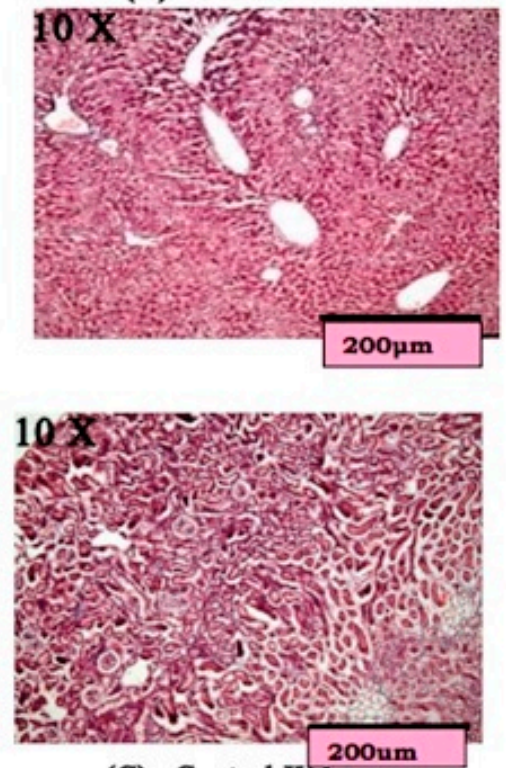

(C) Control Kidney

(E) Control Pancreas
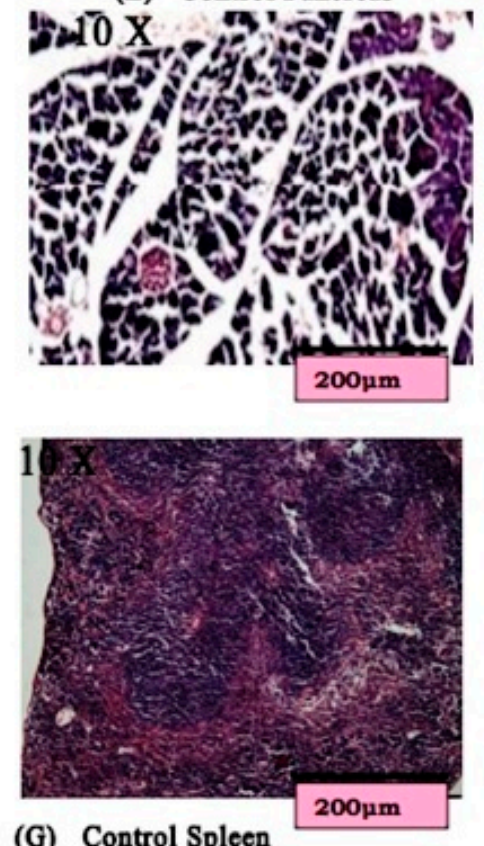

(I) Control Skeletal Muscles

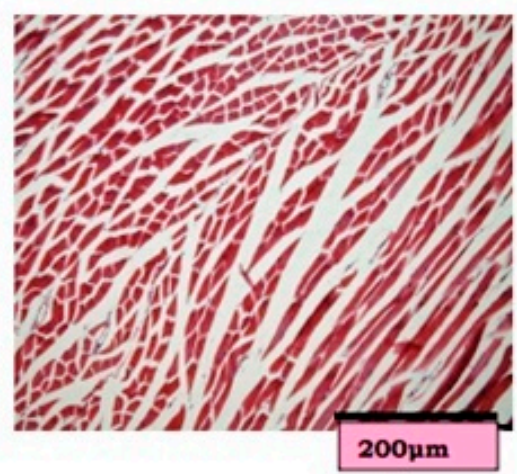

(B) Treatment Liver
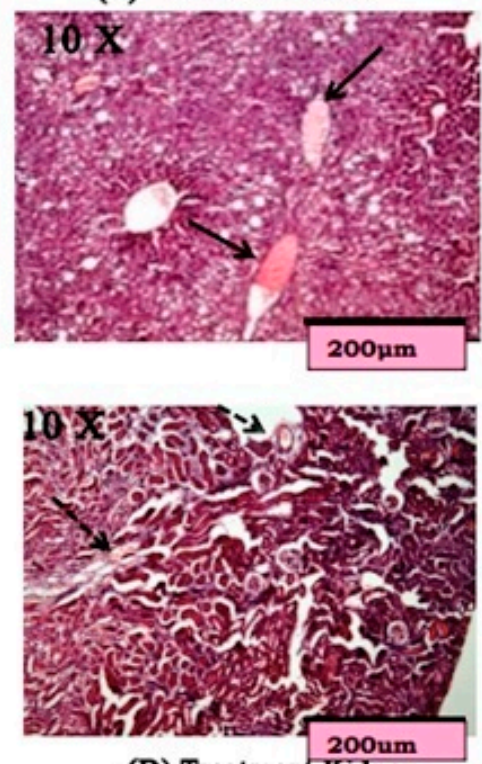

(D) Treatment Kidney

(F) Treatment Pancreas
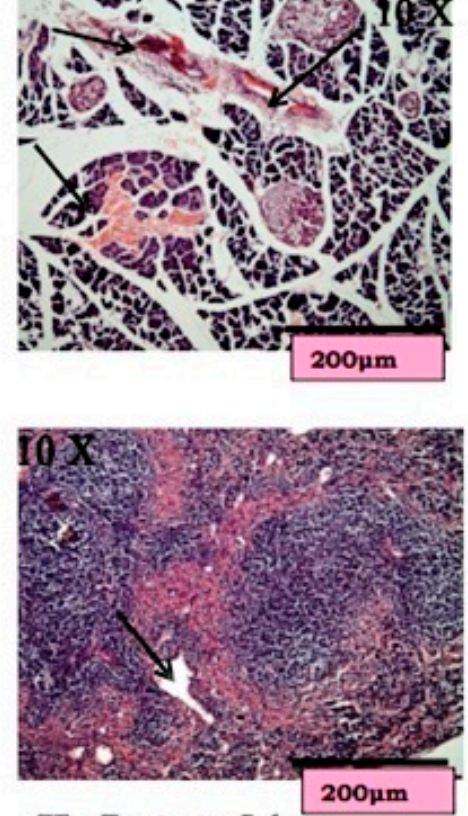

(H) Treatment Spleen

(J) Treatment Skeletal Muscles

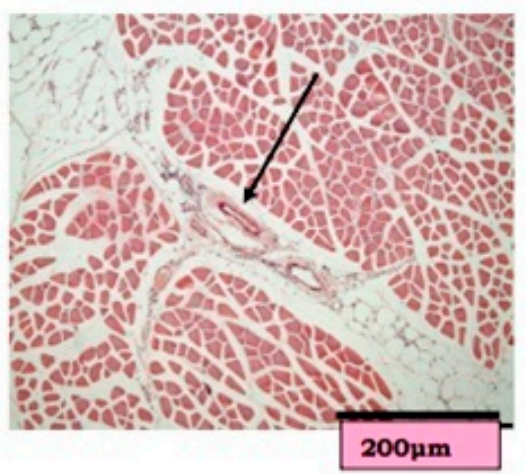


Figure 2: Haemotoxylin and Eosin stained sections of tissues under bright field microscope with 10X (A) Liver (control group) showing normal hepatocytes with normal hepatic venules surrounded by hepatocytes plates. It is showing no aggregation of nuclei. (B) Liver (stressed group) showing vacuolated spaces with clustered nuclei; as shown by single black solid arrow (C) kidney (control group) showing normal symmetry of glomeruli, vessels and tubule along with same thickness of vessels. (D) Kidney (stressed group) showing dilated and flattened bowmen's capsules and clustered nuclei in glomerulus as shown by single dashed arrow. (E) pancreas (control group) showing normal pancreatic acini, islets cells and blood vessels arrangement (F) pancreas (stressed group) showing lymphocytic infiltration in islets cells \& moderate congestion of blood capillaries; shown by thick solid black arrow (G) spleen (control group) showing normal red pulp and white pulp surrounded by fibrous tissues. (H) Spleen (stressed group) showing vacuolated spaces \& megakaryocytes in red pulp and white pulp region as shown by thick solid black arrow. (I) skeletal muscles (control group) showing normal epimysium in both vertical and horizontal fibre $(\mathrm{J})$ skeletal muscles (stressed group) showing mild hyperplasia along with moderate congestion of blood capillaries indicated by thick solid black arrows. 


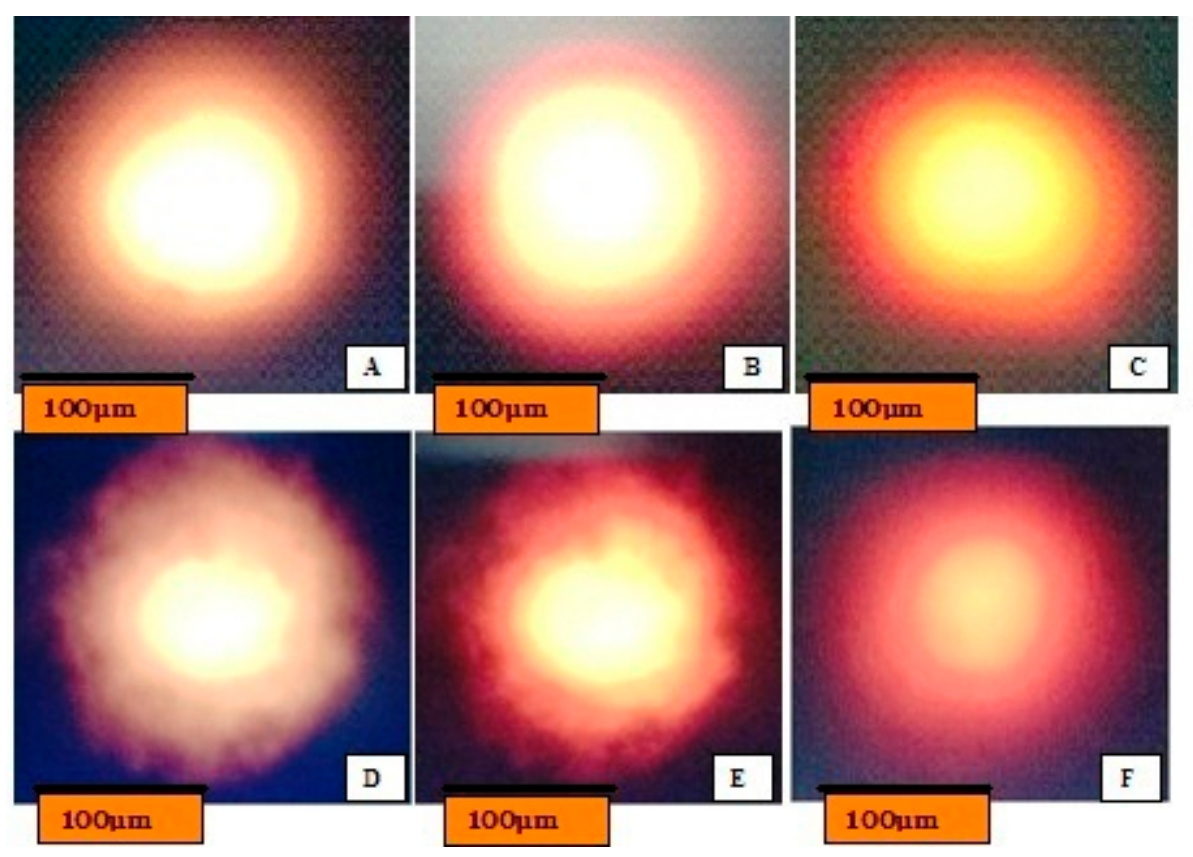

Figure 3: Effect of chronic unpredictable environmental stress on average comet tail length of tissues (A) liver (control group) (B) kidney (control group) (C) pancreas (control group) (D) liver (stressed group) (E) kidney (stressed group) (F) pancreas (stressed group). The images of ethidium bromide stained slides were captured with fluorescent microscope. The comet tail length was measured with Komet 5.5 imaging system to acquire images. 


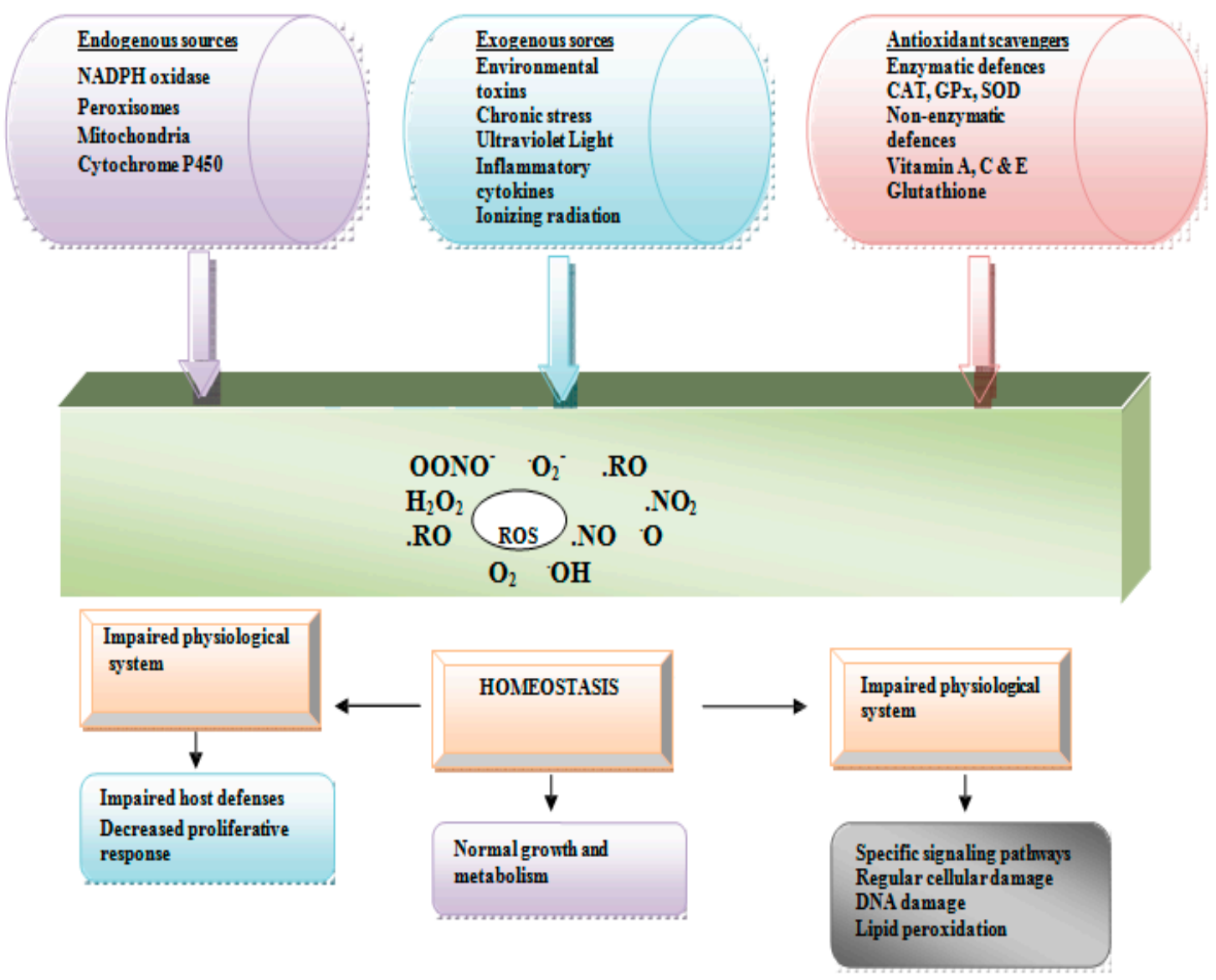

Figure 4: The cellular response and sources of reactive oxygen species (ROS). Generation of ROS results from normal metabolism in mitochondria and peroxisomes along with cytosolic enzymes mechanisms. Numerous external agents can triggers ROS generation. Enzymatic and non-enzymatic antioxidants defence system counteracts these R O S to maintain normal physiological homeostasis. Decrease level of ROS below cutoff value of homeostasis interrupt the physiological role of ROS in host defence and cellular proliferation. Similarly, elevated ROS level accelerate the impairment of homeostasis and lead to detrimental effects on cells and other components of living system. Biomolecules like DNA, RNA, lipids, and proteins several becomes the target of ROS and get damaged. Further increase in ROS may initiate a stress signal that triggers the specific redox-sensitive signaling pathways. 
Table Legends

\begin{tabular}{|l|l|l|l|l|}
\hline Days & Stress time & Stress type & Duration & Conditions \\
\hline Day 1 & $10: 00 \mathrm{hrs}$ & Restraint & $3 \mathrm{hrs}$ & No \\
\hline Day 2 & $11: 00 \mathrm{hrs}$ & Wet bedding $\left(25^{0} \mathrm{C}\right)$ & $2 \mathrm{hrs}$ & No \\
\hline Day 3 & $15: 00 \mathrm{hrs}$ & Forced swim $\left(25^{0} \mathrm{C}\right)$ & $30 \mathrm{~min}$ & No \\
\hline Day 4 & $13: 00 \mathrm{hrs}$ & Crowding & $2 \mathrm{hrs}$ & No \\
\hline Day 5 & $19: 00 \mathrm{hrs}$ & Lights on & Overnight & No \\
\hline Day 6 & $09: 00 \mathrm{hrs}$ & Cold force swim $\left(4^{0} \mathrm{C}\right)$ & $15 \mathrm{~min}$ & $22: 00 \mathrm{hrs,} \mathrm{crowding} \mathrm{overnight}$ \\
\hline Day 7 & $10: 00 \mathrm{hrs}$ & Restraint & $2 \mathrm{hrs}$ & $19: 00 \mathrm{hrs,} \mathrm{food} \mathrm{deprivation} \mathrm{overnight}$ \\
\hline
\end{tabular}

Table I: Chronic unpredictable environmental weekly stress schedule implemented on Swiss albino mice.

\begin{tabular}{|l|l|l|l|l|}
\hline Groups $(\mathbf{n = 2 0})$ & $\begin{array}{l}\text { Fasting blood glucose } \\
(\mathbf{m g} / \mathbf{d L})\end{array}$ & Body weight (Gms) & Feed Weight (Gms) & Feed Efficiency Ratio \\
\hline Control & $93.187 \pm 2.37$ & $26.35 \pm 2.821$ & $49.72 \pm 0.86$ & 54.26 \\
\hline Stressed & $116.10 \pm 10.62$ & $23.63 \pm 1.06$ & $49.91 \pm 1.95$ & 47.90 \\
\hline F Value & 74.89 & 23.408 & 0.160 & 0.236 \\
\hline P Value & $<0.001$ & $<0.001$ & $0.695^{*}$ & $<0.001$ \\
\hline
\end{tabular}

Table II: Repeated measure analysis of variance (RMANOVA) was performed to demonstrate the statistical changes among control and stressed mice. All values are represented as mean $\_$S.D. A p value $(<0.05)$ were considered to be significant. Non significant $p$ values were shown by $*$. 


\begin{tabular}{|c|c|c|c|c|c|c|c|c|}
\hline Group $(n=20)$ & $\begin{array}{l}\text { CAT } \\
\text { (U/mg } \\
\text { protein) }\end{array}$ & $\begin{array}{l}\text { SOD } \\
\text { (U/mg } \\
\text { protein) }\end{array}$ & $\begin{array}{l}\text { GSH } \\
\text { (nmol/mg } \\
\text { protein) }\end{array}$ & $\begin{array}{l}\text { GST } \\
\text { (U/mg of } \\
\text { protein) }\end{array}$ & $\begin{array}{l}\text { Gpx } \\
\text { (nmol/min/mg } \\
\text { protein) }\end{array}$ & \begin{tabular}{|l|} 
HK \\
(moles of glucose \\
phosphorylated/g/h)
\end{tabular} & $\begin{array}{l}\text { F 1, } 6 \text { bis } \\
\text { phosphates } \\
\text { (moles of pi } \\
\text { liberated } \\
/ \mathrm{min} / \mathrm{mg} \text { ) }\end{array}$ & $\begin{array}{l}\text { Glucose-6- } \\
\text { phosphatase } \\
\text { (moles of pi } \\
\text { liberated } \\
/ \mathrm{min} / \mathrm{mg} \text { ) }\end{array}$ \\
\hline $\begin{array}{l}\text { Liver } \\
\text { (control group) }\end{array}$ & $105.12 \pm 6.79$ & $169.17 \pm 6.79$ & $6.91 \pm 0.36$ & $66.02 \pm 3.75$ & $121.29 \pm 3.66$ & $124.08 \pm 17.00$ & $0.29 \pm 0.07$ & $0.18 \pm 0.011$ \\
\hline $\begin{array}{l}\text { Liver } \\
\text { (stress group) }\end{array}$ & $90.20+11.81$ & $140.62+5.34$ & $5.23 \pm 0.54$ & $58.04+1.75$ & $73.44+1.75$ & $102.77 \pm 7.68$ & $0.32+0.05$ & $0.22+0.023$ \\
\hline P-value (Liver) & 0.0278 & $<0.0001$ & 0.0004 & 0.0026 & 0.0001 & 0.0340 & $0.4912 *$ & 0.0049 \\
\hline $\begin{array}{l}\text { Kidney } \\
\text { (control group) }\end{array}$ & $101.19 \pm 3.87$ & $156.28 \pm 6.35$ & $7.37 \pm 0.23$ & $40.96 \pm 3.48$ & $83.51 \pm 5.80$ & $106.62 \pm 8.8$ & $0.19 \pm 0.05$ & $0.20 \pm 0.00$ \\
\hline $\begin{array}{l}\text { Kidney } \\
\text { (stress group) }\end{array}$ & $92.47 \pm 6.34$ & $122.85 \pm 9.22$ & $5.30 \pm 0.50$ & $32.89 \pm 6.56$ & $65.06 \pm 3.60$ & $94.28 \pm 5.76$ & $0.12 \pm 0.04$ & $0.18 \pm 0.15$ \\
\hline P-value(kidney) & 0.0218 & 0.0002 & 0.0001 & 0.0413 & 0.0003 & 0.0312 & $1.0000 *$ & 0.0374 \\
\hline $\begin{array}{l}\text { Pancreas } \\
\text { (control group) }\end{array}$ & $97.55 \pm 7.23$ & $87.58+6.69$ & $6.70+0.79$ & $22.63+2.35$ & $70.70+2.60$ & $115.64 \pm 17.14$ & $0.13+0.048$ & $0.21 \pm 0.01$ \\
\hline $\begin{array}{l}\text { Pancreas } \\
\text { (stress group) }\end{array}$ & $85.92 \pm 6.95$ & $61.45 \pm 5.17$ & $4.71 \pm 0.49$ & $17.50 \pm 1.64$ & $58.28 \pm 7.19$ & $98.13 \pm 4.93$ & $0.10 \pm 0.006$ & $0.199 \pm 0.00$ \\
\hline $\begin{array}{l}\text { P-value } \\
\text { (Pancreas) }\end{array}$ & 0.0320 & 0.0001 & 0.0015 & 0.0040 & 0.0067 & 0.0594 & $0.1901 *$ & $0.1242 *$ \\
\hline $\begin{array}{l}\text { Serum } \\
\text { (control group) }\end{array}$ & $132.1 \pm 5.41$ & $150.5 \pm 4.0$ & $8.19 \pm 0.86$ & $1.27 \pm 0.40$ & $81.83 \pm 2.42$ & - & - & - \\
\hline $\begin{array}{l}\text { Serum } \\
\text { (stressed group) }\end{array}$ & $111.2 \pm 6.20$ & $123.5 \pm 6.60$ & $4.94+0.51$ & $0.96 \pm 0.14$ & $61.86 \pm 5.0$ & - & - & - \\
\hline P-value(Serum) & 0.0005 & $<0.0001$ & $<0.0001$ & 0.0017 & $<0.0001$ & - & - & - \\
\hline
\end{tabular}

Table III: Effect of chronic unpredictable environmental stress on antioxidants activities in serum, liver, kidney and pancreas along with carbohydrate enzymes activity in liver, kidney and pancreas. Statistical differences were evaluated by student unpaired t test. Data are presented 
as mean $\_$SD. A $p$ value $<0.05$ were considered as significant. Non-significant $\mathrm{p}$ value were designated with $*$. CAT $=\mathrm{Catalase}, \mathrm{SOD}=\mathrm{Superoxide}$ dismutase, $\mathrm{GSH}=$ Glutathione, $\mathrm{GST}=$ Glutathione-S-transferase, $\mathrm{Gpx}=$ Glutathione peroxidase, $\mathrm{HK}=$ Hexokinase.

\begin{tabular}{|l|l|l|l|}
\hline Group $(\mathbf{n = 2 0})$ & Liver $(\boldsymbol{\mu m})$ & Kidney $(\boldsymbol{\mu m})$ & Pancreas $(\boldsymbol{\mu m})$ \\
\hline Control & & & \\
\hline Stressed & $4.50 \pm 0.48$ & $6.01 \pm 0.10$ & $5.88 \pm 0.50$ \\
\hline P-value & $24.21 \pm 1.37$ & $27.21 \pm 1.59$ & $26.59 \pm 1.65$ \\
\hline
\end{tabular}

Table I V: Effect of chronic unpredictable environmental stress on DNA damage assessed by comet tail length. Statistical differences were evaluated by student unpaired t test. Data are presented as mean+SD.

\begin{tabular}{|l|l|l|}
\hline Group & Fasting insulin $(\boldsymbol{\mu g} / \mathbf{L})$ & HOMA-IR Index \\
\hline Control $(\mathbf{n}=\mathbf{2 0})$ & $1.06 \pm 0.31$ & $3.89 \pm 1.07$ \\
\hline Stressed $(\mathbf{n}=\mathbf{2 0})$ & $0.51 \pm 0.06$ & $5.13 \pm 1.11$ \\
\hline P-value & $<0.0001$ & $<0.0001$ \\
\hline
\end{tabular}

Table V: Efffect of chronic unpredictable environmental stress on plasma insulin and HOMA-IR. Statistical differences were evaluated by student unpaired t test. Data are presented as mean $\_$SD. 